\title{
Muzealia dotyczące gruźlicy w zbiorach Muzeum Dr. Roberta Kocha w Wolsztynie
}

\author{
Items concerning tuberculosis in the collection \\ of Robert Koch Museum in Wolsztyn
}

\author{
Marcin Adamczak ${ }^{1}$
}

\begin{abstract}
Wolsztyn
Streszczenie: Artykuł przedstawia muzealia dotyczące gruźlicy przechowywane w Muzeum Roberta Kocha w Wolsztynie. Trwający jedenaście lat wolsztyński okres życia był dla Roberta Kocha bardzo ważny ze względu na badania naukowe, które wtedy prowadził. W artykule opisany został dom Roberta Kocha w Wolsztynie, obecnie siedziba Muzeum Roberta Kocha. Scharakteryzowane zostały eksponaty dotyczace prowadzonych przez Kocha badań nad gruźlicą i upowszechniania ich wyników. Ciekawy i obszerny zbiór pamiątek po Kochu został zgromadzony dzięki darczyńcom.
\end{abstract}

Abstract: This article focuses on items concerning tuberculosis and kept in Robert Koch Museum in Wolsztyn. Robert Koch spent eleven years in Wolsztyn and carried out important research on anthrax and tuberculosis here. The house where Koch resided, now the seat of the Museum, is described in detail. Items and memorabilia reminding Koch's early achievements are characterized. Almost all numerous memorabilia were given by donors.

Słowa kluczowe: Robert Koch, gruźlica, Muzeum Roberta Kocha, Wolsztyn

Keywords: Robert Koch, tuberculosis, Robert Koch Museum, Wolsztyn

\section{Wprowadzenie}

Robert Koch (1843-1910) to lekarz i uczony, odkrywca bakterii wywołujących gruźlicę, cholerę, form przetrwalnikowych waglika oraz przyczyn chorób zakaźnych, któremu świat zawdzięcza ocalenie wielu istnień ludzkich. Wraz z Ludwikiem Pasteurem (1822-1895) jest uznawany za twórcę nowoczesnej bakteriologii. Laureat Nagrody Nobla z 1905 r. w dziedzinie medycyny za badania i odkrycia w zakresie gruźlicy, jedenaście lat życia, od 1869 do 1880 r., spędził na ziemi wolsztyńskiej, gdzie rozpoczał swoją działalność badawczą w dziedzinie bakteriologii.

1 Muzeum Regionalne w Wolsztynie. Artykuł stanowi recenzowaną wersję wykładu wygłoszonego 19 maja 2018 r. w Wolsztynie podczas konferencji pt. „Gruźlica - dawne doświadczenia, obecne osiagnięcia i zagrożenia". 


\section{Robert Koch na ziemi wolsztyńskiej}

Robert Koch przybył do ówczesnego powiatu babimojskiego (Kreis Bomst) w Prowincji Poznańskiej (Provinz Posen) z powodów materialnych, w poszukiwaniu lepszych warunków pracy i życia. W 1869 r. przyjechał wraz z żoną Emmą i roczna córeczką Gertrudą do Rakoniewic (Rakwitz), miasta słynącego w początkach XIX w. hodowlą i handlem pijawkami.

Powiat babimojski miał charakter rolniczy i odznaczał się w latach 70. XIX w. uprawą winogrona i chmielu, a także hodowla zwierząt. Siedziba radcy ziemiańskiego (landrata), jak również inne ważne urzędy powiatu, takie jak: sąd, urząd skarbowy, komisariat okręgowy mieściły się w Wolsztynie, który od lat trzydziestych XIX w. stał się siedziba powiatu. W 1871 r. powiat babimojski liczył 18,98 mil kwadratowych ${ }^{2}, 107$ wsi i 7 miast: Babimost (Bomst), Wolsztyn (Wollstein), Kargowa (Unruhstadt), Rakoniewice (Rakwitz), Kębłowo (Kiebel), Kopanica (Kopnitz), Rostarzewo (Rothenburg). Zamieszkiwały go 55103 osoby, miasto Rakoniewice liczyło 2019 mieszkańców, a miasto powiatowe Wolsztyn 2 802. Jeśli chodzi o stosunki narodowe, to dla tego okresu odpowiedni spis przeprowadzono w 1861 r. i wówczas powiat zamieszkiwało 53727 osób, z czego 33852 Niemców i 19875 Polaków³.

Jako młody, dwudziestosześcioletni lekarz Robert Koch prowadził swoją praktykę z powodzeniem i dość szybko zdobył zaufanie pacjentów, kolegów lekarzy oraz lokalnego środowiska. Kiedy wybuchła wojna francusko-pruska, w lipcu 1870 r. zgłosił się w charakterze lekarza ochotnika. W 1872 r. po zdaniu egzaminu państwowego otrzymał posadę lekarza powiatowego (Kreisphysikus) w Wolsztynie. Do wyboru Kocha spośród czterech kandydatów na to stanowisko urzędnicze przyczyniły się władze powiatu babimojskiego i miasta Wolsztyna, które wskazywały na jego wykształcenie i prowadzoną na wysokim poziomie praktykę, rekomendując go na stanowisko lekarza powiatowego. Po złożeniu przysięgi urzędniczej przeprowadził się do Wolsztyna, gdzie zamieszkał w domu przy ulicy Bergstrasse (dziś ul. Doktora Kocha), wcześniej przez mieszkańców zwaną Białą Górą.

Dom, w którym mieszkał i pracował, wraz z oficyna powstał w latach czterdziestych XIX w. z fundacji Angielki Marie Pearce, która w 1843 r. ufundowała na terenie posesji szpital katolicki "Zakład Chorych pod Samarytaninem”. Z czasem "Zakład Chorych..." przeniesiono do innej części miasta, a pomieszczenia wynajmowano. W tym domu na pierwszym piętrze w latach 1872-1880 mieszkał Robert Koch z rodzina. Okazała neogotycka kamienica wzorowana na gotyku angielskim, wybijała się wówczas ponad sąsiadująca zabudowę ulicy4.

Pośrodku budynku znajdowała się brama przejazdowa zakończona łukiem, nad którą wyłaniał się trzyokienny wykusz, z którego roztaczał się piękny widok na jedna z głównych ulic miasta. Mieszkanie doktora Kocha było bardzo przestronne

\footnotetext{
1 mila pruska (w systemie obowiązującym do 1872 r.) wynosiła dokładnie 7532, 5 metrów.

Kalendarz Poznański na rok zwyczajny 1874, Poznań 1873, s. 82.

M. Adamczak, Wolsztyn w XIX wieku, Wolsztyn 2012, s. 63-65; 82-86.
} 


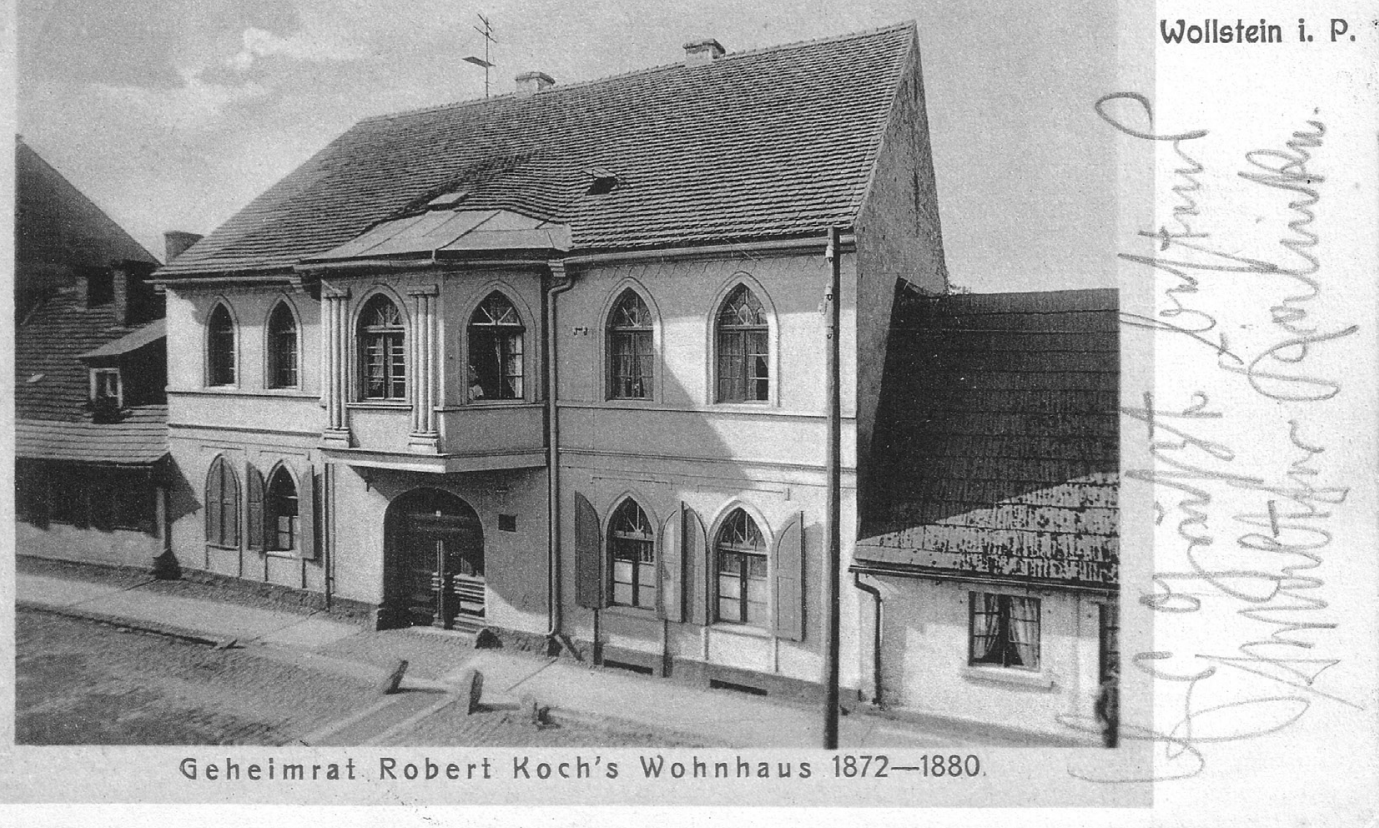

Ryc. 1. Dom, w którym mieszkał Robert Koch

Źródło: Muzeum Regionalne w Wolsztynie - Muzeum Dr. Roberta Kocha (dalej: MRK)

\section{Wotnuing ge. Hlochs.}

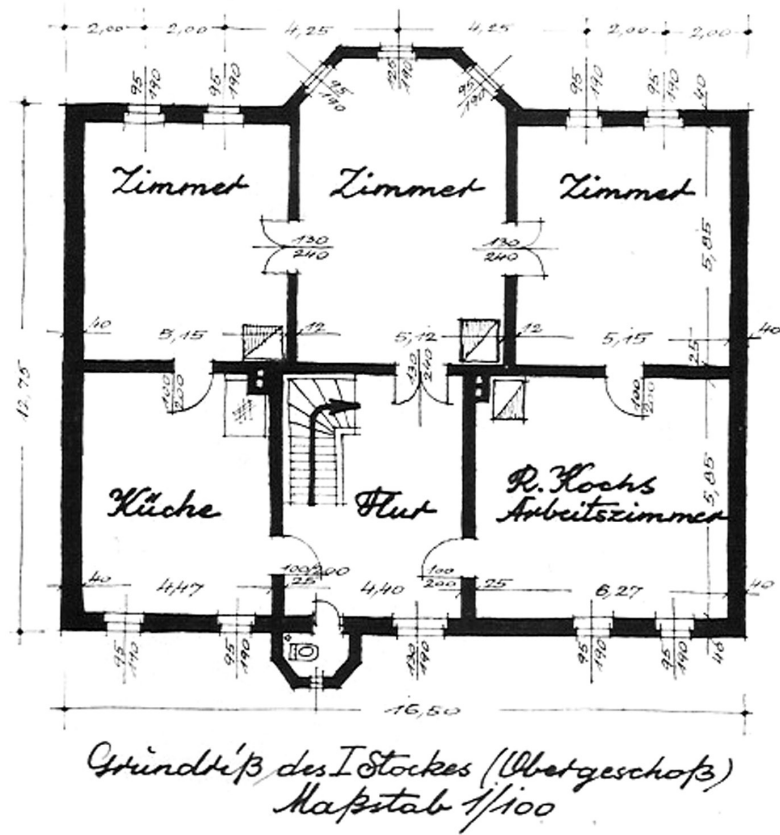

Ryc. 2. Plan mieszkania Roberta Kocha w Wolsztynie Źródło: MRK 
i słoneczne. W pokoju, którego okna wychodziły na podwórze, urządził swój gabinet i małe laboratorium badawcze.

W Wolsztynie poza sprawowaniem funkcji lekarza powiatowego zajął się także badaniami nad drobnoustrojami. Oto jak w nekrologu pośmiertnym na łamach „Nowin Lekarskich” w 1910 r. scharakteryzował początek prac naukowych Kocha w Wolsztynie dr Filip Eisenberg:

Po wojnie z 1870, w której brał udział, przeniósł się w r. 1872 do Wolsztyna jako fizyk okręgowy i tu poczyna się właściwy okres twórczy, który każdego musi przejąc najwyższym podziwem. $Z$ dala od dobrze wyposażonych pracowni, bez wskazówek i fachowej pomocy sam stworzył sobie pracownię, w której skromnymi środkami udało mus się prześcignąć uczonych najlepiej przez los i społeczeństwo wyposażonych ${ }^{5}$.

W Wolsztynie po trzech latach badań dokonał opisu cyklu rozwojowego bakterii waglika i w $1876 \mathrm{r}$. obwieścił to światu nauki publikując prace „Etiologia zachorowań na waglik” ${ }^{\text {w }}$ czasopiśmie „Beiträge zur Biologie der Pflanzen” wydawanym przez niemieckiego botanika i mikrobiologa prof. Ferdynanda Cohna we Wrocławiu. W Wolsztynie prowadził dalsze prace badawcze i napisał wiele artykułów naukowych, m.in. „O metodzie barwienia i fotografowania bakterii"

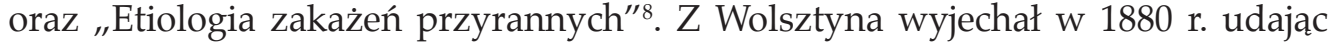
się do Berlina, gdzie został członkiem Cesarskiego Urzędu Zdrowia (Kaiserliche Gesundheitsamt). W świadomości mieszkańców zapisał się jako bardzo dobry lekarz, który mimo prowadzonej przez rząd polityki germanizacyjnej był życzliwy Polakom?.

\section{Pamięć o Robercie Kochu w Wolsztynie}

Pamięć o Robercie Kochu i jego wolsztyńskich latach była w Wolsztynie trwała. Jeszcze za swojego życia, pod koniec XIX w., Robert Koch miał w Wolsztynie ulice swojego imienia (obecnie ul. Krótka). Przez władze miasta odznaczony został także tytułem Honorowego Obywatela Miasta.

Po odzyskaniu przez Polskę niepodległości Wolsztyn w wyniku udanego Powstania Wielkopolskiego znalazł się w granicach II Rzeczypospolitej. Pamięć o Robercie Kochu była wciąż żywa, a ówczesny burmistrz Klemens Modliński, wśród obiek-

5 F. Eisenberg, Robert Koch. Wspomnienie pośmiertne, „Nowiny Lekarskie”, 1910, nr 8, s. 506-509.

6 Die Ätiologie der Milzbrand-Krankheit, begründet auf die Entwicklungsgeschichte des Bacillus Anthracis, 1876.

7 Verfahren zur Untersuchung, zum Konservieren und Photographieren der Bakterien, 1877.

Aetiologie der Wundinfectionskrankheiten, 1878.

Szerzej o wolsztyńskich latach Roberta Kocha: W. Genschorek, Robert Koch, Leipzig 1979, s. 31-71; B. Rusch, Robert Koch. Vom Landarzt zum Pionier der modernen Medizin, München 2010, s. 50-67; R. K. Meissner, Wolsztyńskie lata Roberta Kocha za szczególnym uwzględnieniem badan etiologii zachorowań na waglik, [w:] R. Koch, Etiologia zachorowań na waglik, Poznań - Wolsztyn 1996. 
tów godnych zwiedzenia w mieście wymieniał „dom, w którym pracował sławny prof. dr Robert Koch"10.

W 1958 r. z inicjatywy środowisk lekarskich na terenie nieruchomości przy ul. Roberta Kocha 12, utworzono Izbę Pamięci, ukazująca życie i działalność noblisty. $\mathrm{Z}$ inicjatywy dr. J. Kłonieckiego do Wolsztyna trafiły pierwsze kopie dokumentów, zdjęcia i sprzęt mikroskopowy, a także popiersia Roberta Kocha oraz portrety wielkich uczonych (J. Lister, R. Virchow, I. Semmelweis, L. Pasteur, J. Henle, I. Miecznikow, E. Behring) wykonane przez artystę Jerzego Winklera. Stanowiło to początek izby pamięci poświęconej uczonemu, której oficjalne otwarcie miało miejsce 22 października $1958 \mathrm{r}$.

Muzeum Dr. Roberta Kocha, będące częścią Muzeum Regionalnego, powstało 2 maja 1996 r. z inicjatywy Fundacji Polsko-Niemieckiej i Stowarzyszenia Naukowego im. Roberta Kocha. Stanowi ono kontynuację działającej od 1958 r. Izby Pamięci, poświęconej uczonemu ${ }^{11}$. W dwóch salach na parterze, w lewym skrzydle budynku, w którym mieszkał i pracował Robert Koch przedstawiane sa pamiątki związane z wielkim uczonym. Ekspozycje dotycza okresu pobytu Kocha w Wolsztynie, jak i innych miejsc Europy i świata, w których prowadził on swoje badania. Stylowe meble, sprzęt laboratoryjny i medyczny oraz inne pamiątki oddają klimat przełomu XIX i XX w., czasów, w jakich żył i pracował naukowiec. $\mathrm{W}$ gablotach prezentowane sa fotografie i dokumenty związane $\mathrm{z}$ działalnościa noblisty.

Muzeum prowadzi badania, działalność edukacyjną i lekcje muzealne. Współpracuje $\mathrm{z}$ fundacjami i towarzystwami naukowymi, organizuje konferencje i spotkania.

Wśród organizacji działających na rzecz pamięci o Robercie Kochu i popularyzacji nauki należy wymienić Stowarzyszenie Naukowe im. Roberta Kocha w Wolsztynie, które powołane zostało do życia w 1995 r. Celem jego działalności jest upowszechnianie wiedzy o życiu i pracy naukowca Roberta Kocha ze szczególnym uwzględnieniem okresu zamieszkiwania przez niego na ziemi wolsztyńskiej, a także promowanie badań naukowych z zakresu mikrobiologii, pulmonologii oraz innych specjalności z zakresu nauk medycznych. Stowarzyszenie od chwili założenia organizuje konferencje i sympozja naukowe. Już w początkach swojej działalności Stowarzyszenie nawiązało kontakty i współpracuje z Instytutem Roberta Kocha w Berlinie.

\section{Zbiory związane z gruźlicą w Muzeum Dr. Roberta Kocha w Wolsztynie}

24 marca 1882 r. Robert Koch zadziwił cały naukowy świat ogłaszając odkrycie Mycobacterium tuberculosis - bakterii wywołującej gruźlicę. W sali Towarzystwa Fizjologicznego w Berlinie zaprezentował wyniki swoich badań. Wykład zostałbardzo

10 Archiwum Państwowe w Lesznie, Akta miasta Wolsztyn, sygn. 512.

11 R. K. Meissner, Przedmowa, [w:] R. Koch, Etiologia zachorowań na waglik, Poznań - Wolsztyn 1996, s. 5-10. 
Privatarchiv

Wolfgang Pfuhl

Nienburg Weser

\section{Dem Andenken an Robert Koch}

überreicht

von der Redaktion und dem Verlag:

Separat-Abdruck aus der

Zeitschrift für Tuberkulose.

Herausgegeben von

B. Fränkel, G. Gaffky, R. Kooh, F. Kraus, E, v, Leyden, W, v, Leube. Redaktion: Prof. Dr. A. Kuttner.

Band XVI. Heft 2.

IgIo.

\section{Leipzig,}

Johanin Ambrosius Barth.

Dörrienstraße 16. 
dobrze przygotowany, w sali ustawiono wiele mikroskopów, a preparaty były przygotowane tak, aby każdy ze słuchaczy mógł zapoznać się z wynikami badań. Swoja prezentację Koch zakończył słowami:

Da się z tego wyprowadzić wniosek, że właściwą przyczyną gruźlicy są swoiste bakterie, a co za tym idzie, chorobę tę należy zaliczyć do pasożytniczych.

Było to doniosłe odkrycie, ponieważ w tamtych czasach w Europie jedna trzecia populacji ludzkiej umierała na gruźlicę. Dzień pierwszej prezentacji Kocha dotyczącej etiologii gruźlicy uznano na całym świecie jako „Dzień walki z gruźlicą” i jest każdego roku obchodzony 24 marca $^{12}$. Warto również wspomnieć, że w nazewnictwie polskim bakterie gruźlicy są często nazywane na cześć bakteriologa „prątkami Kocha".

W zbiorach Muzeum Dr. Roberta Kocha znajduję się przedruk słynnego wykładu Roberta Kocha „Die Ätiologie der Tuberkulose (Nach, einem in der Physiologischen Gesellschaft zu Berlin am 24. März 1882 gehaltenen Vortrage), Von Dr. Robert Koch, Regierungsrat im Kaiserl. Gesundheitsamt". Wspomniany druk został wydany w Lipsku w 1910 r., w roku śmierci noblisty, poprzedzony jest liczacym 10 stron opisem sylwetki Roberta Kocha pióra prof. Dr. Martina Kirchnera. Wydawnictwo jest jednym z kilku darów dla wolsztyńskiego Muzeum od prawnuka Roberta Kocha Wolfganga Pfuhla.

4 sierpnia 1890 r. w Berlinie miał miejsce X Międzynarodowy Kongres Lekarski. Siedem tysięcy lekarzy i naukowców akredytowało swój pobyt na kongresie. Ze względu na tak dużą ilość uczestników na miejsce obrad wybrano ogromny budynek cyrku Renz. Większość osób przyjechała mając nadzieję wysłuchać wystapienia Kocha i innych wybitnych naukowców, licząc na nowe odkrycia medyczne, zaś rząd niemiecki pragnął pochwalić się dokonaniami swoich badaczy.

Robert Koch przedstawił wykład na temat walki z gruźlica i wspomniał o nowo opracowanej substancji, która miała być przypuszczalnie skutecznym lekiem na gruźlicę nazwanej „tuberkuliną”. W swoim przemówieniu zaznaczył, „że tylko nadzieja, która widzi w tym leku, zmusiła go, wbrew zwykłym zwyczajom, do udzielania informacji jeszcze przed ukończeniem badań"13. Jak się później okazało, tuberkulina nie sprawdziła się jako lek na gruźlicę i rozczarowała zarówno świat nauki, jak i rzesze chorych, którzy liczyli na skuteczne remedium na chorobę trapiąca miliony ludzi na świecie. W kręgach naukowych pojawiły się głosy krytykujące Kocha za propagowanie tajnego i niebezpiecznego leku. Tuberkulina nie znalazła zastosowania jako lek przeciwko gruźlicy, jak tego spodziewał się Koch, ale jest wykorzystywana jako test diagnostyczny, tzw. próba tuberkulinowa ${ }^{14}$.

12 J. M. Wiśniewski, J. E. Bielecki, Robert Koch (1843-1910), „Kosmos”, t. 59, 2010, s. 21.

13 T. Goetz, Cudowny lek, Kraków 2015, s. 260-268; J. M. Wiśniewski, J. E. Bielecki, Robert Koch (18431910), „Kosmos”, t. 59, 2010, s. 23.

14 Z. Zwolska, Robert Koch - bakteriolog, lekarz, humanista. Pamięci uczonego w 170. rocznice Jego urodzin, „Nauka”, nr 4, 2013, s. 167. 

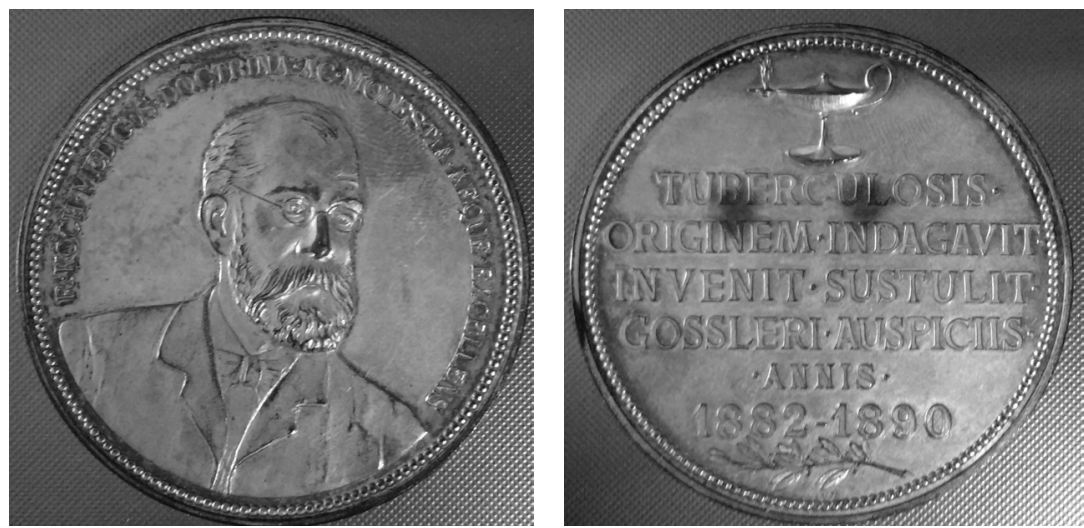

Ryc. 4. Medal z 1890 r.

Źródło: MRK

Z tego okresu pochodzi eksponat ze zbiorów wolsztyńskiego Muzeum, którym jest posrebrzany medal z brazu. Medal ma średnice $5 \mathrm{~cm}$. na awersie posiada wizerunek Roberta Kocha i łaciński napis „R. KOCH. MEDICUS. DOCTRINA. AC. MODESTIA. AEQUE. EXCELLENS". Na rewersie widoczny symbol kaganka oświaty i łaciński napis „TUBERCULOSIS. ORIGINEM. INDAGAVIT. INVENIT. SUSTULIT. GOSSLERI. AUSPICIIS. ANNIS 1882-1890".
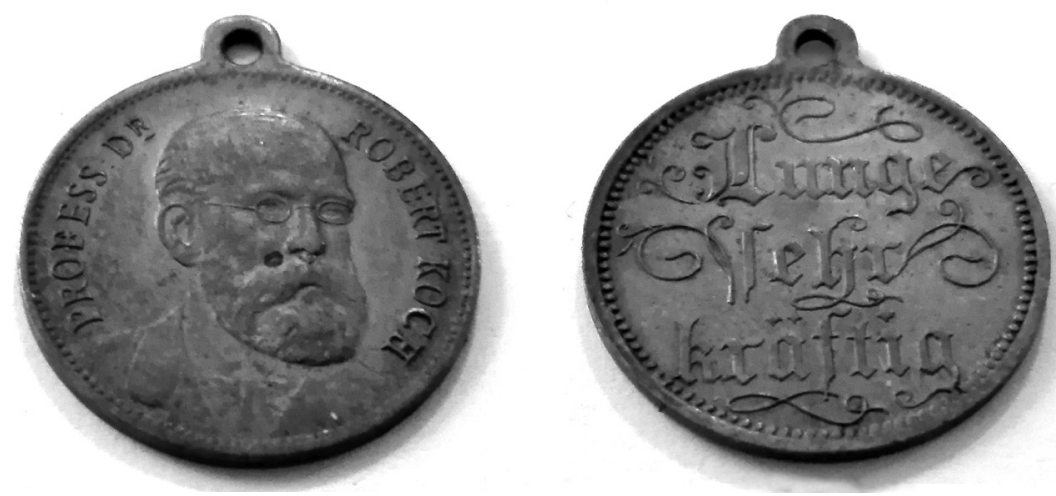

Ryc. 5. Wisiorek z wizerunkiem Roberta Kocha.

Źródło: MRK

Kolejnym interesującym eksponatem z czasów Kocha jest rodzaj medalika czy też wisiorka. Na awersie widać Roberta Kocha i napis „PROFESS DR ROBERT KOCH”. Na rewersie napis „LUNGE SEHR KRÄFTIG”, co można tłumaczyć jako „płuca bardzo krzepkie". 
Muzeum eksponuje profesjonalne fotografie prątków gruźlicy ze zbiorów Zakładu Mikrobiologii Instytutu Gruźlicy i Chorób Płuc w Warszawie, będące darem prof. Zofii Zwolskiej. W Muzeum można także obejrzeć pod mikroskopami preparaty bakteriologiczne różnych bakterii chorobotwórczych, a przede wszystkim rozmazy prątków gruźlicy barwionych metodą Ziehl-Nelseena.

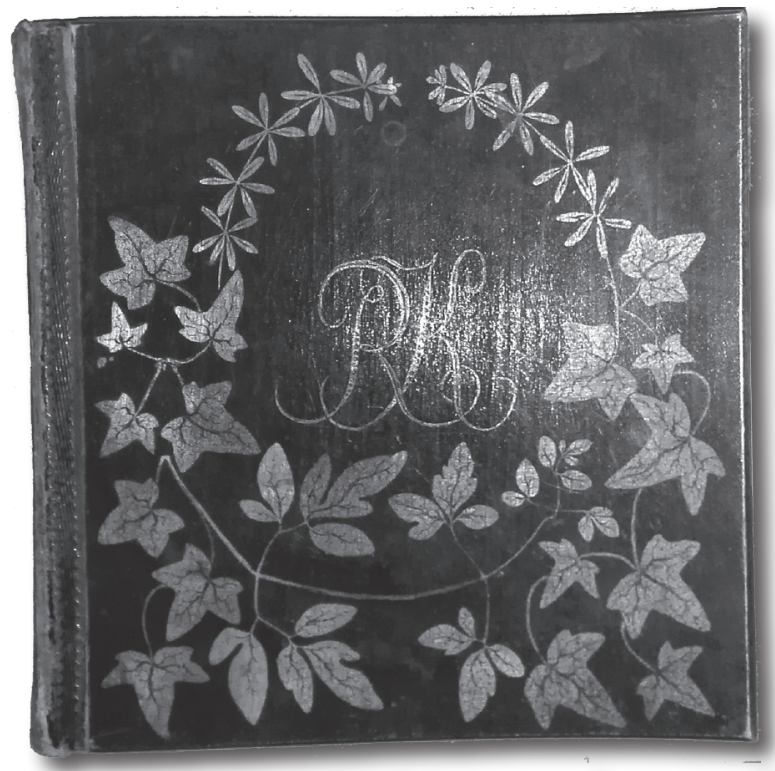

Ryc. 6. Skrzynka na preparaty Roberta Kocha.

Źródło: MRK

Bardzo interesującym eksponatem jest oryginalna skrzynka na preparaty szkiełkowe, której używał Robert Koch. Drewniane pudełko o wymiarach 20x20x4,3 cm, na grzbiecie posiada napis „Mikroskopische Praeparate” zaś na górze inicjały imienia i nazwiska naukowca „R.K.” otoczone liśćmi. Jest darem prof. Marii Krystyny Pietkiewicz (1924-2007).

\section{Zbiory literatury dotyczącej Roberta Kocha i medycznej z XIX i XX w. w Muzeum Dr. Roberta Kocha w Wolsztynie}

Muzeum posiada księgozbiór liczący ponad 150 woluminów, wśród których znajdują się książki, wydawane na przestrzeni od XIX do XXI w., dotyczące Roberta Kocha oraz specjalistyczna literatura z zakresu nauk medycznych. Na księgozbiór składa się głównie literatura niemiecka i polska. Pośród ksiażek można znaleźć tytuły omawiające zagadnienia związane z gruźlicą. Niektóre z nich posiadają tablice z ilustracjami ukazującymi preparaty bakteriologiczne. Poniżej przedstawia się kilka wybranych tytułów z ikonografią bakteriologiczną z epoki. 


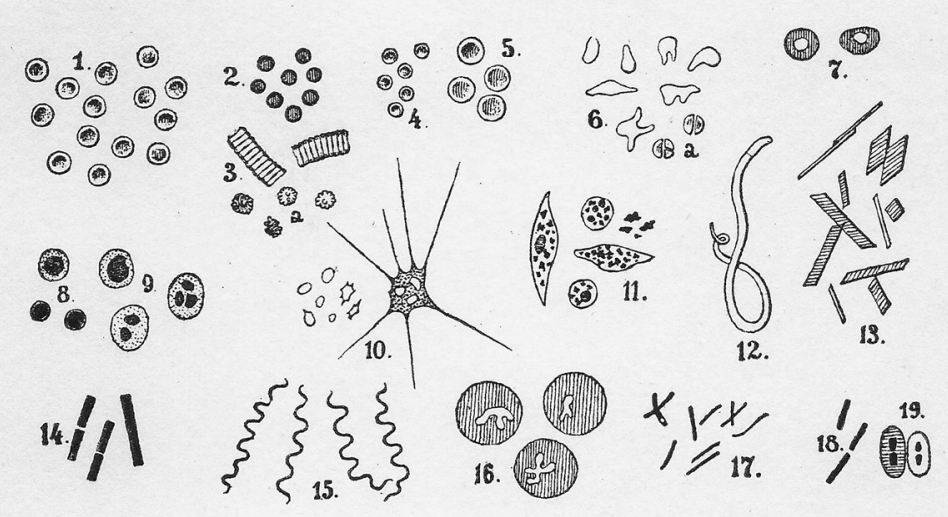

Ryc. 7. Rycina przedstawiająca bakterie w książce z 1892 r.

Źródło: MRK

Tablica z podręcznika diagnostyki klinicznej Greaber'a ${ }^{15}$ pochodzi z 1892 r. Pod numerem 14 widoczne bakterie waglika (wolsztyńskie odkrycie Kocha), a pod numerem 17 bakterie gruźlicy.

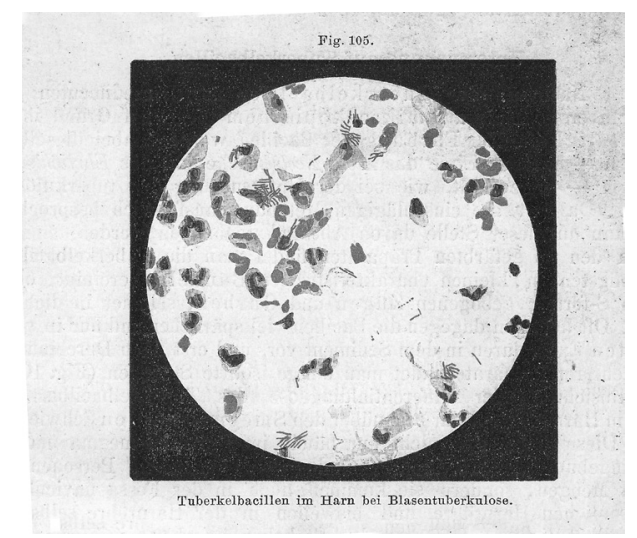

Ryc. 8. Tablica z bakteriami gruźlicy w książce z 1904 r.

Źródło: MRK

Rysunek przedstawia bakterie gruźlicy w moczu chorego. Zamieszczono go w podręczniku klinicznych metod badawczych z 1904 r. autorstwa Eulenburg'a, Kolle'go i Weintraud' $a^{16}$.

15 E. Greaber, Leitfaden der klinischen Diagnostik von Blut, Auswurf, und Harn, Basel 1892. 1904.

A. Eulenburg, W. Kolle, W. Weintraud, Lehrbuch der Klinischen Untersuchungsmethoden, Berlin - Wien 


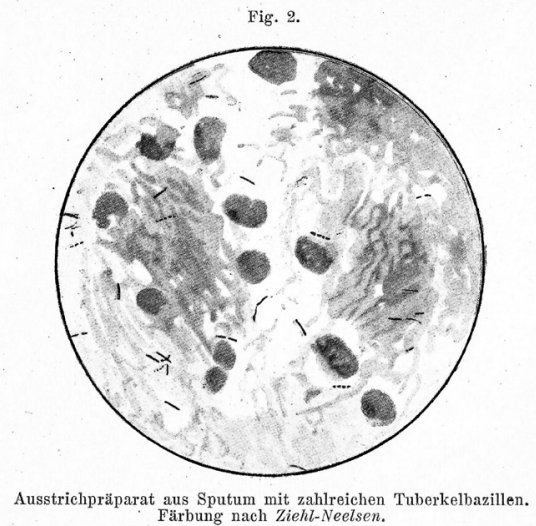

Ryc. 9. Tablica z bakteriami gruźlicy w książce z 1918 r.

Źródło: MRK

Kolejny rysunek przedstawia preparat z bakteriami gruźlicy z plwociny osoby chorej barwionymi metodą Ziehl-Neelsena. Książka z 1918 r., autorów M. Klopstocka i A. Kowarsky'ego, dotyczy praktyk klinicznych, chemicznych, mikroskopijnych i bakteriologicznych metod badawczych ${ }^{17}$. Jest to piąte wydanie tego podręcznika.

\section{Walory filatelistyczne związane z Robertem Kochem i gruźlicą w zbiorach Muzeum Dr. Roberta Kocha w Wolsztynie}

Filatelistyka to kolekcjonowanie różnego rodzaju walorów pocztowych, przede wszystkim znaczków pocztowych, ale także datowników okolicznościowych, całostek, całości pocztowych i kopert FDC (skrót od angielskiego: first day cover) ${ }^{18}$. Filatelistyka rozwinęła się wkrótce po pojawieniu się znaczka pocztowego w $1840 \mathrm{r}$. W XX w. należała do najpopularniejszych form kolekcjonerstwa (ok. $200 \mathrm{mln}$ zbieraczy na świecie) $)^{19}$.

Filatelistyka odzwierciedla różne aspekty życia społecznego, gospodarczego, kulturalnego jak też naukowego. Dlatego oczywistym jest, że Robert Koch jak i walka z gruźlicą doczekały się mnóstwa znaczków, właściwie w każdym zakątku świata ${ }^{20}$.

17 M. Klopstock, A. Kowarsky, Praktikum der klinischen, chemischen, mikroskopischen und bakteriologischen Untersuchungsmethoden, Berlin - Wien 1918.

18 Jest to koperta z naklejonym znaczkiem pocztowym, zazwyczaj ostemplowana stemplem okolicznościowym w pierwszym dniu obiegu znaczka. Koperta i stempel posiadają zazwyczaj napisy wskazujące na pierwszy dzień obiegu znaczka.

19 Nowa encyklopedia powszechna PWN, Warszawa 1998, t. 2, s. 344-345.

20 Z okazji różnych rocznic wyemitowano znaczki pocztowe związane z Robertem Kochem i gruźlica m.in. w takich krajach jak: Afganistan, Algieria, Andora, Argentyna, Bahamy, Bangladesz, Belgia., Benin, Bułgaria, Chiny, Czad, Egipt, Filipiny, Francja, Gabon, Ghana, Gwinea, Indie, Jemen, Jugosławia, Kajmany, Komory, Kongo, Kuba, Malediwy, Mauritius, Meksyk, Mozambik, Niemcy, Peru, Polinezja, Polska, Portugalia, Republika Dżibuti, Republika Południowej Afryki, Republika Środkowoafrykańska, Republika Zielonego Przylądka, Rumunia, Rwanda, San Marino, Somalia, Sri Lanka, Surinam, Syria, Szwajcaria, Szwecja, Tajlandia, Tanzania, Uganda, Wegry, Wietnam, Zair, Zimbabwe, ZSRR. 
Można tu wymienić znaczki, które ukazywały się z okazji m.in.: 50 rocznicy śmierci Roberta Kocha, 75 i 100 rocznicy przyznania mu Nagrody Nobla, 150 rocznicy urodzin Kocha oraz chyba najliczniej reprezentowana na całym świecie 100 rocznica odkrycia bakterii gruźlicy ${ }^{21}$.

Na wielu znaczkach widoczny jest krzyż z podwójnym ramieniem, tzw. krzyż lotaryński, który jest symbolem organizacji walczących z gruźlicą.

Poniżej prezentowane jest kilka wybranych walorów filatelistycznych ze zbiorów Muzeum Dr. Roberta Kocha w Wolsztynie.

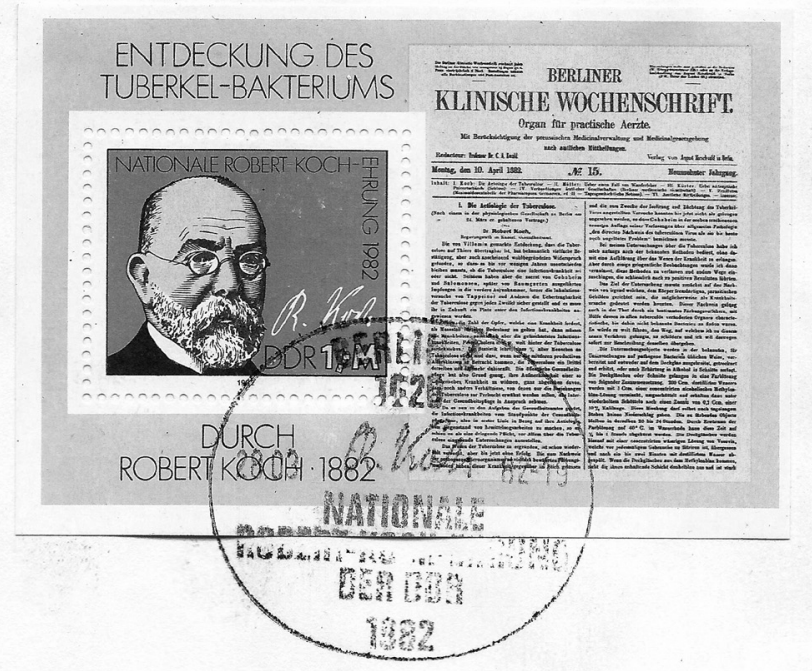

Ryc. 10. Niemcy 1982 r.

Źródło: MRK

Znaczek z okazji setnej rocznicy odkrycia pratka gruźlicy został wydany w Niemieckiej Republice Demokratycznej (DDR) w 1982 r. Znaczek w bloku przedstawia postać Roberta Kocha, a obok znajduje się pierwsza strona „Berliner Klinische Wochenschrift" z 10 kwietnia 1882 r., czasopisma naukowego, w którym ukazał się słynny wykład Kocha o etiologii gruźlicy.

Z okazji setnej rocznicy odkrycia bakterii gruźlicy Poczta Polska wyemitowała znaczek z wizerunkiem Roberta Kocha o wartości 10 zł oraz drugi przedstawiający polskiego bakteriologa Odo Bujwida (1857-1942) o wartości 25 zł. Na kopercie widoczna jest także pieczęć okolicznościowa z Wolsztyna z datą 11.10.1982.

Warto w tym miejscu przytoczyć fakt, że nazwę tuberkulina zaproponował Odo Feliks Kazimierz Bujwid, która służyła na początku do określania nieoczyszczonej tu-

21 R. Fuhrmann, Robert Koch in der Philatelie, [w:] Robert Koch zum 150. Geburtstag: 1843-1993, Clausthal-Zellerfeld 1993, s. 62-65. 


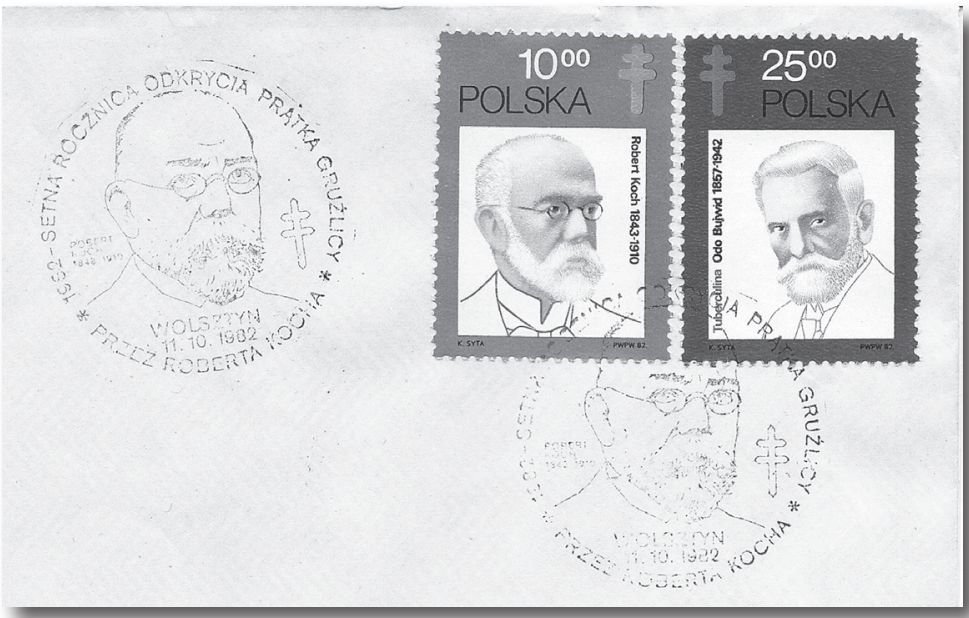

Ryc. 11. Polska 1982 r.

Źródło: MRK

berkuliny, tzw. starej tuberkuliny ${ }^{22}$. Bujwidowi zawdzięczamy również tekst ${ }^{23}$, w którym opisuje uczestnictwo w wykładach bakteriologicznych prowadzonych przez Roberta Kocha w Berlinie w 1885 r.

Kolejnym interesującym okazem muzealnym jest koperta wraz ze znaczkiem z wizerunkiem Roberta Kocha z okolicznościowym stemplem z Dormerton w Republice Południowej Afryki z datą 24 marca 1982 r.

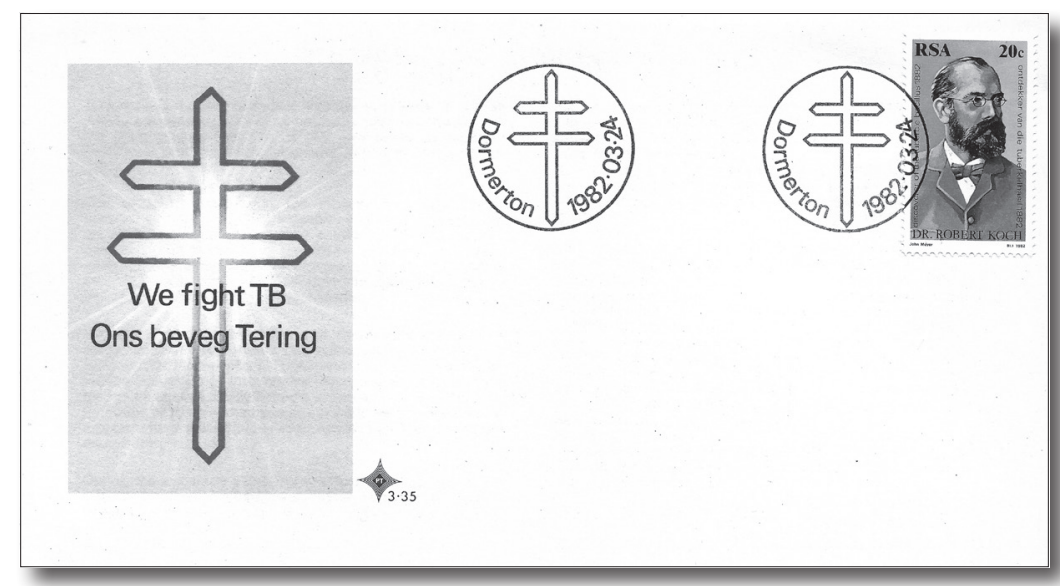

Ryc. 12. RPA 1982 r.

Źródło: MRK

22 J. M. Wiśniewski, J. E. Bielecki, dz. cyt., s. 23.

${ }_{23}$ O. Bujwid, Z pracowni prof. Roberta Koch'a. (Z wycieczki naukowej odbytej kosztem Kasy pomocy naukowej imienia Dr. J. Mianowskiego), Warszawa 1886. 


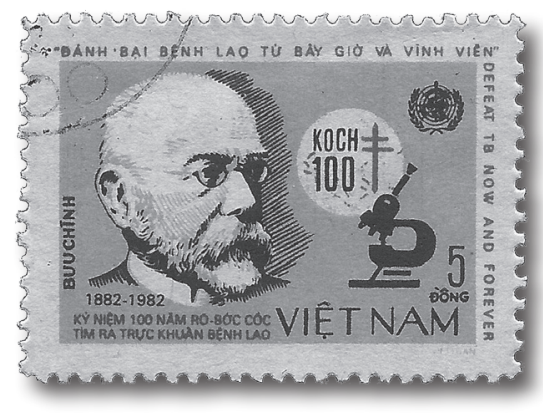

Ryc. 13. Wietnam 1982 r.

Źródło: MRK

Powyższy znaczek wyemitowany został w Wietnamie w 1982 r., również z okazji setnej rocznicy odkrycia pratków gruźlicy. Znaczek posiada nominał 5 dongów wietnamskich.

Przedstawione w niniejszym artykule muzealia są zaledwie małym wycinkiem zbiorów Muzeum Dr. Roberta Kocha w Wolsztynie, które sukcesywnie stara się powiększać kolekcję eksponatów związanych z Robertem Kochem, jak również z zakresu bakteriologii i nauk medycznych. Zbiory Muzeum powiększaja się również w wyniku ofiarowanych eksponatów od Darczyńców, za co autor artykułu pragnie Im wszystkim w tym miejscu serdecznie podziękować.

Wykaz źródeł:

Archiwum Państwowe w Lesznie, Akta miasta Wolsztyn, sygn. 512.

\section{Wykaz literatury:}

1. Adamczak M., Wolsztyn w XIX wieku, Wolsztyn 2012.

2. Aetiologie der Wundinfectionskrankheiten, Lepzig 1878.

3. Bujwid O., Z pracowni prof. Roberta Koch'a. (Z wycieczki naukowej odbytej kosztem Kasy pomocy naukowej imienia Dr. J. Mianowskiego), Warszawa 1886.

4. Die Ätiologie der Milzbrand-Krankheit, begründet auf die Entwicklungsgeschichte des Bacillus Anthracis, Leipzig 1876.

5. Eisenberg F., Robert Koch. Wspomnienie pośmiertne, „Nowiny Lekarskie”, 1910, nr 8, s. 506-509.

6. Eulenburg A., W. Kolle, W. Weintraud, Lehrbuch der Klinischen Untersuchungsmethoden, Berlin - Wien 1904.

7. Fuhrmann R., Robert Koch in der Philatelie, [w:] Robert Koch zum 150. Geburtstag: 1843-1993, Clausthal-Zellerfeld 1993, s. 62-65.

8. Genschorek W., Robert Koch, Leipzig 1979. 
9. Goetz T., Cudowny lek, Kraków 2015.

10. Greaber E., Leitfaden der klinischen Diagnostik von Blut, Auswurf, und Harn, Basel 1892.

11. Kalendarz Poznański na rok zwyczajny 1874, Poznań 1873.

12. Klopstock M., Kowarsky A., Praktikum der klinischen, chemischen, mikroskopischen und bakteriologischen Untersuchungsmethoden, Berlin-Wien 1918.

13. Meissner R. K., Przedmowa, [w:] R. Koch, Etiologia zachorowań na waglik, Poznań - Wolsztyn 1996, s. 5-10.

14. Meissner R. K., Wolsztyńskie lata Roberta Kocha za szczególnym uwzględnieniem badań etiologii zachorowań na waglik, [w:] R. Koch, Etiologia zachorowań na waqglik, Poznań - Wolsztyn 1996, s. XVII-XXX.

15. Nowa encyklopedia powszechna PWN, Warszawa 1998, t. 2.

16. Rusch B., Robert Koch. Vom Landarzt zum Pionier der modernen Medizin, München 2010.

17. Verfahren zur Untersuchung, zum Konservieren und Photographieren der Bakterien, 1877.

18. Wiśniewski J. M., Bielecki J. E., Robert Koch (1843-1910), „Kosmos”, t. 59, 2010, s. 21-23.

19. Zwolska Z., Robert Koch - bakteriolog, lekarz, humanista. Pamięci uczonego w 170. rocznice Jego urodzin, „Nauka”, 2013, nr 4, s. 145-176. 